\title{
Conceptualization of the terms of self and the sense of identity and their disorders in the course of schizophrenia in the works of Polish authors
}

\author{
Konceptualizacja pojęć Ja i poczucia tożsamości oraz ich zaburzenia \\ w przebiegu schizofrenii w pracach polskich autorów
}

\section{Hanna Karakuła-Juchnowicz ${ }^{1,2}$ AEF, Justyna Morylowska-Topolska² ${ }_{\text {AEF }}$}

${ }^{1}$ I Department of Psychiatry, Psychotherapy and Early Intervention, Medical University of Lublin, Poland

2 Department of Clinical Neuropsychiatry, Medical University of Lublin, Poland

\begin{abstract}
A defined and formed identity is the foundation of human mental functioning. The sense of one's own existence as an individual, together with the conscious image of oneself, plays a fundamental role in regulating behaviors. The ability to see the limits of one's own body is a significant milestone in human development, because it allows the development of a global sense of self, and that is the basis for the process of identifying one's own identity.

The paper presents the contribution of Polish researchers (psychiatrists and psychologists) to understanding the phenomenon of the sense of self, identity, and their disorders with particular emphasis on schizophrenia.

Method: A review of the available literature by Polish authors on the subject was undertaken by searching the following databases: Polish Bibliography of Medicine, CEJS, NUKAT and National Library Database, using the keywords: identity, self, personality, schizophrenia, ego, within time frame: 1970-June 2017. The article includes only those works which made the original contribution of Polish authors to research on the issue of self and the sense of identity, with particular emphasis on their disorders in schizophrenia.

Results: The works of three Polish authors: J. Reykowski, J. Kozielecki and Z. Zaborowski deserve particular attention in the context of the definition of self and the sense of identity.

The works of A. Kępiński, in turn, have contributed to understanding the problem of disorders of self in schizophrenia. Kępiński's psychopathological concept was based on the analysis and description of the pathology of self, the pathology of the boundary self-the world, disorders of time-space order and the hierarchy of values. In these terms, he considered the structure of the psychotic world, especially in schizophrenia and melancholy. In his opinion, schizophrenic psychosis manifests itself primarily in the form of the blurring of the boundary self-the world and the pathology of self.

The paper also presents the contribution of J. Zadęcki, M. Rzewuska, J. Wciórka, S. Steuden, M. Huflejt-Łukasik to understanding the disorders of the sense of self in schizophrenia.

Conclusions: The views of Polish authors presented in the paper are an interesting contribution to world literature on research into disorders of self in schizophrenia.
\end{abstract}

Keywords: self, ego, identity, schizophrenia

\section{Streszczenie}

Określona ukształtowana tożsamość jest fundamentem funkcjonowania psychicznego człowieka. Poczucie własnego istnienia jako jednostki razem z uświadomionym obrazem własnej osoby pełni podstawową rolę w regulacji zachowań. Umiejętność dostrzeżenia granic własnego ciała stanowi wielki przełom w rozwoju człowieka, ponieważ umożliwia pojawienie się globalnego poczucia Ja, a to stanowi podstawę procesu dookreślania własnej tożsamości.

Celem niniejszego artykułu jest przedstawienie wkładu polskich badaczy (psychiatrów i psychologów) w rozumienie zjawiska poczucia Ja, tożsamości i ich zaburzeń, ze szczególnym uwzględnieniem schizofrenii.

Metoda: Dokonano przeglądu dostępnej literatury polskich autorów dotyczącej poruszanej problematyki, korzystając z baz danych: Polskiej Bibliografii Lekarskiej, CEJS, NUKAT oraz Bazy Biblioteki Narodowej, używając słów kluczowych: Ja, tożsamość, self, jaźń, schizofrenia, osobowość oraz deskryptorów czasowych: 1970- maj 2017. W artykule uwzględniono jedynie te prace, które stanowiły oryginalny wkład polskich autorów do badań nad zagadnieniem Ja i poczucia tożsamości, ze szczególnym uwzględnieniem ich zaburzeń w przebiegu schizofrenii.

Wyniki: Na szczególną uwagę w kontekście definiowania zjawiska Ja oraz poczucia tożsamości zasługują prace trzech polskich autorów: J. Reykowskiego, J. Kozieleckiego oraz Z. Zaborowskiego.

Do zrozumienia problematyki zaburzeń $J a$ w schizofrenii przyczyniły się z kolei przede wszystkim prace A. Kępińskiego. Podstawą koncepcji psychopatologicznych Kępińskiego była analiza i opis patologii Ja, patologii granicy Ja-świat oraz zaburzeń porządku czasowo-przestrzennego i zaburzeń hierarchii wartości. W tych kategoriach rozpatrywał on strukturę świata psychotycznego, zwłaszcza w schizofrenii i melancholii. Jego zdaniem, psychoza schizofreniczna przejawia się głównie w postaci zatarcia granicy Ja-świat oraz 
patologii Ja. W pracy zaprezentowano także wkład J. Zadęckiego, M. Rzewuskiej, S. Steuden, J. Wciórki, M. Nieznańskiego M. HuflejtŁukasik w rozumienie zaburzeń doświadczenia $J a$ w zaburzeniach schizofrenicznych.

Wnioski: Zaprezentowane w artykule poglądy polskich autorów dotyczące tego zagadnienia stanowią ciekawy wkład do literatury światowej w zakresie badań nad zaburzeniami Ja w schizofrenii.

Słowa kluczowe: Ja, self, jaźń, tożsamość, schizofrenia

\section{Introduction}

A defined and formed identity is the foundation of human mental functioning [1]. The sense of one's own existence as an individual $[2,3,4]$, together with the conscious self-image, plays a fundamental role in regulating behaviors [1].

Defined in the literature of the subject as: "sense of self" or "self-identity", it seems to be an obvious human attribute and therefore its disorders have been widely described by personality theorists [5] and psychiatrists [6, 7]. This issue was discussed in relation to the origins of disorders such as personality disorders, neuroses or depressive syndromes $[4,7,8,9]$, however, it seems particularly interesting to look at disorders of self occurring in the course of schizophrenia, which, according to some authors $[6,10,11,12]$, are its essence.

As early as the 1970 s, studies on schizophrenia disorders were conducted in Poland $[6,13,14]$. It should be emphasized that after the end of the World War II, Poland, following the Allies' agreement in Yalta, found itself behind the Iron Curtain, within the Soviet sphere of influence until 1989 [15]. Limited contacts with international academic research greatly hindered the exchange of scientific thought, which was the reason why the works of Polish authors from that period were rarely known behind the Polish western border.

This paper aims to present the contribution of Polish researchers (psychiatrists and psychologists) to understanding the phenomenon of the sense of self, identity, and their disorders with a special focus on schizophrenia.

\section{Method}

The available literature by Polish authors on the subject was reviewed by searching the following databases: Polish Bibliography of Medicine, CEJS, NUKAT and National Library Database, using the key words: identity, self, personality, schizophrenia, ego, within time frame: 1970-June 2017. This article includes only those works that were the original contribution of Polish authors to the study of self and the sense of identity, with particular emphasis on their disorders in the course of schizophrenia.

For clarity, the article is divided into the following parts:

1. Basic concepts and theories on the issues of self and identity

2. The concepts of three Polish authors on the issues of self and identity:
2.1. Janusz Reykowski (1975)

2.2. Józef Kozielecki (1986)

2.3. Zbigniew Zaborowski (1989)

3. Self and identity in the clinical aspect, with particular emphasis on disorders of self in the course of schizophrenia in Polish authors' research:

3.1. Antoni Kępiński (1972)

3.2. Jerzy Zadęcki $(1973,2013)$

3.3. Małgorzata Rzewuska (1988)

3.4. Stanisława Steuden (1997)

3.5. Jacek Wciórka (1997)

3.6. Mirosława Huflejt-Łukasik (2010)

4. Conclusions

\section{Basic concepts and theories on the issue of self and identity}

The terms self and "identity" are quite often used interchangeably, with each of them having many definitions [1].

In addition to the aforementioned terms, i.e. the sense of self and identity, other definitions related to this subject can be found in the literature, such as selfknowledge $[5,16]$, system of models and conceptual visions of oneself [2], cognitive self-presentation [5], or selfconsciousness [17].

Many authors $[1,18]$ in their works on the self draw on the nineteenth-century concept of self by James [19], who was the first to introduce the division into the "subjective" self and the "objective" self $[1,19,20]$. This concept was later expanded by Rogers' phenomenological school [4].

In Rogers' view, a conscious representation of one's own existence and functioning develops in interaction with people who are important for us, creating a the image of self, which consists of our perceptions concerning our own characteristics, our relationships with others and with the world [21, 22].

At present, the term self is used in a broader sense, including: the experiences of a given person, his/her subjective perception of himself/herself - his/her observations, thoughts and feelings about himself/herself, and the efforts made to direct and regulate his/her own behaviour [1, 23].

Other authors combine the concepts of self and identity, but they do not treat them as synonymous [24, 25, 26]. Identity is considered by these authors to be a cognitive representation, a dynamic expression of the processes of self-consciousness conditioned by a specific structure of personality, especially the structure of self. 
Another presentation of the relationship of the two concepts is given by Płużek [27] and Chlewiński and Grzywa [28], treating identity as a synonym of subjective self and the self-image as a synonym of the objective self.

In the literature on the subject, identity and the sense of self still function in two other aspects: as personal identity [1], including the awareness of oneself, one's own cohesion in time and space and at the same time the awareness of one's own distinctness and uniqueness [5], and social identity - expressing the relations with other people and affiliation to social groups [29].

The formation of self structure and the sense of identity in the human ontological development. A person after birth has no sense of existence as a separate individual from the rest of the world - it is the symbiotic phase. According to the theory of relationship with an object, the next phase of personal development - the separation phase - is a multi-stage phase in which a child gains a sense of separateness [30,31]. The ability to see the limits of one's own body is a significant milestone in human development, as it allows for the emergence of a global sense of self, which, in turn, is the basis for the process of identifying one's own identity [29, 32].

The experience of being oneself means that we live our lives from the perspective of the first person, as present self, in singular, temporarily permanent, bodily. Josef Parnas, basing on the phenomenological perspective, uses the term of minimum (basic) self, referring to formulating the experiences from the perspective of the first person. During personal development, the minimal self overlaps with more complex structures that ultimately make up what we call the identity of the individual. Minimum self is also associated with the automatic experiencing the world in which the individual lives. The world is conceived by default, treated as the obvious background of all experiences. Such reception of the surrounding world is a natural ontological characteristics of human beings [33].

There are many mechanisms underlying perceiving the world "from our own perspective". The early form is called cognitive generalization of one's own experiences, preferences, beliefs that come from the feeling that others are similar to self. Later, egotistical distortions occur in the perception of self and the world to maintain a good self-image and thereby to maintain the sense of selfesteem [29].

During ontogenesis, specific needs of self are formed and the failure to satisfy them leads to a functional imbalance in one's own image and thus throughout the regulatory process [3].

Erikson's identity crisis of adolescence and early maturity is also an important stage in identity formation $[30,34]$.
The ideal self is rarely achieved because it is a very complicated process, while a dissonance between the real and the ideal self-image is necessary for the proper development of the personality of the individual who, through dissatisfaction with one's self-image, can constantly change and improve $[4,9]$.

\section{The concepts of Janusz Reykowski, Józef Kozielecki and Zbigniew Zaborowski on the issues of self and} identity

Here we should refer to the works of three Polish authors - Reykowski, Kozielecki and Zaborowski. Their concepts make a valuable contribution to the knowledge of the sense of self and identity.

\subsection{Janusz Reykowski's concept (1975)}

According to Reykowski, the author of the regulatory theory of personality, there are three basic needs of self: the need to preserve the identity (i.e. integrity of self), the need to preserve self-esteem, and the need to maintain control of one's environment $[3,5]$.

These needs are closely interrelated and manifest themselves to a less or more extent for the so-called supporting information. Supporting information is intended to confirm the sense of identity, self-esteem and control. The demand for supporting information depends on the level of development of the self-image. The lack or deficiency of information confirming one's self-image is a threat to self which leads to excessive self-centeredness (egocentrism) in which the person oneself becomes the only point of reference for his/her own actions $[18,35,36]$.

\subsection{Józef Kozielecki's concept (1986)}

Kozielecki's theory of self-knowledge also gained popularity. Self-knowledge is a complex structure consisting of descriptive and value judgments, personal standards and rules for generating and communicating knowledge about oneself. Self-knowledge can be characterized by a variety of contradictions, the number and intensity of which are dependent on many factors. These contradictions make it difficult to adapt to reality and prevent rational actions, which may be reflected in development of psychopathological symptoms and syndromes $[16,18]$.

\subsection{The concept of Zbigniew Zaborowski (1989)}

Zbigniew Zaborowski is the author of the theory of content and forms of self-awareness [17, 24]. The content of self-awareness may include perceptual data, thoughts, judgments, feelings, desires, plans, individual's behavior, performed roles, social relations and so on. They do not operate in an arbitrary, random or chaotic way. The order 
of their functioning is introduced by forms of selfawareness [37].

Zaborowski distinguishes four forms of selfawareness: individual, external, defensive, and reflective. Individual awareness is connected with personal, emotional processing of content on the basis of the self structure. An individual with self-awareness plans and programs his or her goals and tasks, identifies with them, experiences emotions, makes personal attributions. Persons with higher self-awareness are generally egocentric, introverted, and often have internal locus of control. Defensive self-awareness, in turn, is linked to coding and processing of internal and external content on the grounds of fear and danger. People who express this form of self-awareness are strongly focused on themselves. Defensive self-awareness occurs in under conditions of stress, failure, neurosis, physical or mental illness. External self-awareness consists in coding and processing content in an objective, socially-oriented way. It is based on social norms and standards. The subject sometimes renounces subjectivity, and treats his/her relationships with others and the world as well as his/her experiences impartially, objectively. External self-awareness facilitates efficient execution of tasks, fosters effective collaboration and social adaptation. Reflective awareness is characterized by generalized, abstract processing of content, integration of internal and external, mostly semantic, information. This is the highest form of self-awareness that enables effective self-regulation, self-realization, and creative adaptation to a given environment $[17,24]$.

\section{Self and identity in the clinical aspect, with particu- lar emphasis on disorders of self in schizophrenia in Polish authors' research}

As a result of passing through successive stages of development, people differ in the degree to which they have achieved a sense of identity that is expressed by a sense of separateness from their environment and a sense of internal coherence. They also differ in degree of fixation at an early stage of development or regression to these stages. This fixation and regression determine the pathology of sense of identity [30].

Previous experiences that shaped self affect the functioning of a person and his/her vulnerability to psychiatric disorders [1].

Identity disorders are considered either on the basis of what the patient feels and reports, or on the basis of the discrepancy between what a person says and the actual situation, e.g. that he/she is a different person. Regarding what a person feels and reports, there are many elements that can be disturbed in various mental disorders [1].
Sokolik [30], for instance, distinguishes six types of identity disorders:

1. The sense of loss of boundary between oneself or one's environment, the sense of self-destruction

2. Lack of inner content, sense of emptiness, no sense of life

3. Lack of orientation, knowledge of who you are

4. Lack of sense of continuity with self from the past, non-recognition of oneself, a feeling of depersonalization, which can affect the person as a whole or only the physical or mental aspects.

5. Sense of breaking up self into parts, i.e. lack or loss of internal cohesion, including the division into the psyche and body, being an internal observer and hiding the true self for fear that others will destroy it.

6. Sense of unreality of one's own existence, of its absence, the impression of being unreal, dead.

Identity disorders have been addressed in the context of many psychiatric disorders $[4,6,7,8,9]$, and special attention should be given to the problem of disorder of self in the course of schizophrenic psychoses. This subject, despite the fact that was undertaken by such psychiatric classics as Minkowski [38] and Jaspers [39], was beyond the mainstream of schizophrenia research for many years.

\subsection{Antoni Kępiński's views on disorders of self in schizophrenia (1972)}

In Poland, mainly the works of Antoni Kępiński [6, $40,41]$ contributed to understanding the problems of disorders of self in schizophrenia.

Kępiński, the author of the original concept of human information metabolism, distinguished 3 essential elements in the world of experiences:

1. Self which is the focal point

2. A boundary that separates the internal and the external world

3. The specific temporal-spatial order according to which experiences are arranged.

In addition to the temporal-spatial order, the valuation order (hierarchy of values) plays an important role in the subjective sense [41].

Through this boundary, the information metabolism of the body with the external world takes place [42, 43].

The works of Kępiński, "Schizophrenia" [6], "Melancholy" [9], and "Fear" [44], make a permanent contribution to the world literature in the field of phenomenological and anthropological psychiatry [41].

The author devoted considerable space to the analysis of temporality and spatiality, and especially the category of space-time, being a result of the transfer of implication of relativity theory to the phenomenology. According to him, the extent of space-time expansion is a meas- 
ure of evolution, and there is a direct proportional relationship: the higher the level of development, the wider the space-time, for example, through the movement and activity, living beings expand their space-time $[6,41]$.

Kępiński distinguished several types of phenomenological space, e.g. living space, individual and shared space, free and restricted space, open and closed space, real and experienced space $[6,41,44]$.

He emphasized the interdependence of space-time, feelings and mood. He also stressed the peculiarities of experiencing spatiality, such as its heterogeneity and variability. The living space, which according to the terminology used by Kępiński covers all other forms of spatiality, should enable a person to reach self-fulfillment. Limiting this space is tantamount to limiting human development [41].

Kępiński's concept of psychopathology is based on the analysis and description of pathology in terms of all the attributes of the phenomenological world. In terms of pathology of self, pathology of boundary, space-time disorder, and disorders of hierarchy of values, he studied the structure of the psychotic world, especially in schizophrenia and melancholy $[6,9,41,42]$. In his view, schizophrenic psychosis manifests itself primarily in the pathology of boundary and the pathology of self.

The pathology of boundary is expressed in the form of autism and the breakdown of the boundary between the inner and outer world, resulting in delusions, hallucinations, projection and emotional introjection, transitivism, psychic automatism or, for example, the sense of omnipotence.

In turn, the pathology of self in schizophrenia manifest itself, according to Kępiński, among others in: lack of freedom of self, loss of ability to integrate, distortion of the sense of reality of self (hence, for example, depersonalization, derealization), loss of identity, change in self-image, splitting of self, breaking of self, or crystallization of the broken self in an imaginary role $[6,41]$.

The changes described above are simultaneously accompanied by the pathology of the space-time order (e.g. "stopping" of time, breaking of time continuity, freedom of movement in space, "swelling" of self, "pulsing" of self, and loss of valuation order $[6,41]$.

The most characteristic symptom of schizophrenia, according to Kępiński, is the distortion of spatial coordinates - the feeling that the surrounding world gets closer, which is called physiognomy. According to existential psychiatry, this term means a situation in which the surrounding world presses on the patient as if he were the only one in the world, everything has some meaning. It may also be the opposite situation where the surrounding world moves away from the patient, he/she feels surrounded by emptiness and nothingness, nothing around happens, nothing matters. Sometimes the patient feels as if the world around him/her came too close, or moved away [41].

\subsection{Jerzy Zadęcki's findings and views on disorders of self in schizophrenia $(1972,2013)$}

An extremely ambitious task was taken in the years 1968-1972 by Jerzy Zadęcki as part of the research for his PhD thesis, "Disorders of emotional life in early schizophrenia, or on aspirations, intentions, values, self-image and relationships with others" $[13,14]$. Based on the method of phenomenological analysis, he studied the emotional life of patients with schizophrenia. As the author recalls, his method of scientific work based on the subjective description of patients' experiences did not initially gain much interest and favour due to its distinctness from the universally accepted paradigm of the natural sciences [14]. His thesis supervisor was Professor Antoni Kępiński, whose premature death prevented him from participation in his student's doctoral defence.

The author analyzed the phenomenological narrative of as many as 60 patients, which is, due to the size of the study group, a phenomenon without precedent. Typically, this type of research is based on the Binswanger model (analysis of one person's speech) or covers 4-25 people [45]. Initially, the analysis was devoted, as the title of the PhD dissertation suggested, to the feelings experienced by patients in relation to the crisis of reality, time coordinates, value coordinates, disintegration of feelings. After many years, on the new wave of interest in existential phenomenology in psychiatry, the author reinterpreted his earlier observations and identified seven forms of disorder of self in early schizophrenia, which in Heidegger's terminology correspond to Dasain, or forms of being-in-the-world [46]. The characteristic mode of existence (modus vivendi) corresponded to each category which included aspirations, feelings, values, body experiences, experiences of others.

1. Weak and dependent self - subordinate to authority, characterized by lack of spontaneity, poverty of expression, and lack of own opinion and initiative. The experience of self is accompanied by feelings of embarrassment, shame, sense of stasis, hidden from his/her environment. The impasse associated with the lack of initiative is the most evident outside the family environment in confrontation with new tasks.

2. Consolidating of self around spiritual aspirations when the whole attention of the patient is focused on a specific activity of seeking a way to resolve feelings of tension, anxiety, or feelings of emptiness. Finding the truth of "who am I, who really are other people?" is often associated with the intensity of artistic creativity or religious practices, which are accompanied by 
a feeling of contact with others and oneself in the presence of God, described in mystical experiences. At the time of interruption or inhibition of these activities, patients are normally not able to take any other activity.

3. The experience of confusion of self - when patient's increased activity is accompanied by confusion about goals and values. Life decisions are made inadequately, often dictated by a sudden change in emotional attitudes, combined with loss of self as a permanent point of reference in time and space. Chaos refers not only to life decisions but also to feelings, which entails a lack of commitment, in extreme cases absolute relativism of values. Patients have difficulty in identifying their identity in relation to the historical sense of the collective, as well as the commitments that they have made with others, by saying "I do not know who I am".

4. Experiencing the mask of self - the experience of self as false and artificial. The experience of the mask in early schizophrenia is related to the loss of its instrumental function, which allows communication with the environment and is perceived by the surrounding environment as being inhibited. Breaking of the mask is associated with the sudden release of inner experiences, hidden emotional complexes, most often related to parents, in the form of disordered sentences. Consequences come down to difficulties in initiating and sustaining social contacts, daily functioning, loss of tact and nuance appropriate in social contacts.

5. The experience of losing self - as a consequence of unexpected events, failures on the way to reach the goal, loss of the mask, usually in situations of taking total control by others, lack of intimate contact with one's own body, the experience of losing self occurs. Patients, from the position of the ideal observer, describe the experiences of depersonalization, a lack of feelings, or completely deny their own existence, "I do not exist".

6. The alleged realization of self - imaginary, when subjective experience obscures the rational perception of events. During the prodromal phase, pragmatic evaluation is gradually replaced by subjective experience, which ultimately leads to the creation of one's own, "my own" (Latin: solum ipsem) subjective reality. At the next stage of the disease at the moment of crystallization of delusions, subjective experience dominates real experience.

7. The acquired identification of self - the search for truth is linked with the loss of certainty about our own goals and values to be guided by. Gradually, crystallization of delusions of identities with feelings of exaltation, sense of being selected, develops. The declarative sentences, like "I am the second Newton" are accom- panied by the experience of supposed self-realization and is related with abandoning practical activity [14].

The author points out that the essence and significance of the described disorders of self may not be obvious in the early phase of schizophrenia, as the transformation, reorganization and development of disorders can be extended over time.

It should be emphasized that the results of Zadęcki's work have also become a canvas for one of the forms of psychotherapy conducted in a psychotherapeutically oriented environmental program in the centers of community psychiatry in Cracow [47]. Selected fragments of the work are reviewed by patients after acute psychotic symptoms withdraw or are the subject of reflection in their individual or group context. This practice resulted from the need signaled by patients, of understanding the experiences that led to hospitalization, and had enigmatic character for them and their environments. The process of gaining insight in this case consists on the one hand in the identification of different experiences in the analyzed material, and on the other, in the observation of their occurrence in themselves.

The narrative structure that a patient develops as a result of reflection on the phenomenological material collected in the work allows to reinforce or reconstruct one's own self, thereby reproducing the aspirations, hierarchy of values and life goals that are likely to be fulfilled [14].

\subsection{Małgorzata Rzewuska's findings regarding disor- ders of self in schizophrenia (1988)}

Rzewuska [48], using the Polish version of Christopher Scharfetter's Ego-Psychopathology (EPP) questionnaire, sought relationships between disorders of selfperception and the course of illness in 185 patients suffering from schizophrenia. The EPP questionnaire used in the study evaluates five aspects of the ego pathology: disorders of identity (consistency and permanency of self in various conditions and over time), activity (authorship of one's own experiences and behaviors), vitality (sense of one's own vigour), coherence (self-integrity), demarcation (clear boundaries between oneself and one's environment) [49].

The results obtained by the author [48] encouraged her to divide schizophrenic psychoses into three groups:

I. The first group was composed of $25 \%$ of the respondents, in whom a slow development of the disease was observed, while the positive symptoms increased in the course of the disease. In this group, the process of partial disintegration, defined as proliferation, weakened the coherence between the subsystems, but allowed for developing new relationships. In the positive symptoms, some structuralisation was identified (links between persecutors, frequent hallucinations of voices talking to each other, delusional interpretation 
of events). The disintegration of the personality function (as a whole) often led to formal thought disorders and clear deterioration of social adjustment. During the relapses, the disorder of cohesion, identity and vitality increased. Frequent occurrence of comprehensible symbolism in positive symptoms indicate that this type of disintegration is associated with the "shift" of one's own experiences into the sphere of the environmental assessment.

II. The second group was made up of $35 \%$ of respondents whose positive symptoms were constantly focused around themselves. In this group, the disease had acute onset, and its relapses were numerous. Disintegration was most strongly expressed in this group, personalities of patients were "degraded". Here, negative symptoms were most clear. Strong association of symptoms with one's own personality (depersonalization, hypochondriac delusions) suggests that in the process of disintegration, patients transfer events related to their environment into the inner sphere of self-evaluation.

III. The third group accounted for $40 \%$ of respondents whose symptoms were constantly associated with a real environment. Social adaptation of these patients was quite good, frequently with long remissions, and with late onset of illness. Disorder of identity and cohesion with an environment was noted less often, however, the sense of the blurred boundary between self-environment, was frequent.

The author suggested that such a division into groups makes it possible to use more targeted therapeutic interventions in such a heterogeneous group of patients with diagnosed schizophrenia. For instance, in patients with severe disintegration long-term pharmacotherapy seems preferable, while in those with strong integration mechanisms - targeting psychotherapeutical interventions on the improvement of the self-environment boundary (long-term administration of antipsychotics seems to be doubtful in this group of patients).

\subsection{Stanisława Steuden's findings on disorders of self in schizophrenia (1997)}

Steuden, in a study conducted for her habilitation thesis, "The dynamics of personality changes in people with schizophrenia", assessed the dynamics of self and the subjective sense of personality change in schizophrenic patients who had been under observation for fifteen years [18]. The most intense personality changes were found in the first period of illness. This included, among others, anxiety the feeling of being different, alienated and misunderstood. In all studies (conducted both at the onset of illness and after more than a decade from the onset), the majority of the patients had a disoriented sense of one's own identity. The patients had a vague conception of themselves, a sense of conflict between different spheres of perception and self-presentation, and there was a lack of integration between the external and internal dimensions of self. Over time, there was a relative stability with regard to identity disorders in the respondents. Disoriented selfidentity was associated with a lack of sense of continuity of the self (when the patient has a feeling that he/she is not the person he/she was before) and belonging (inability to determine who he/she is in relation to his/her family, social or professional group). In addition, it was interesting to note that the greatest differences between men and women, both in terms of range and severity of disorders of sense of identity, occurred in the first three months, decreasing after several years of the disease [18].

\subsection{Jacek Wciórka's views on the role of disorder of self in schizophrenia (1997)}

Constructing the scale of Clinical Assessment of Schizophrenic Syndrome (KOZS) for the clinical evaluation of psychopathological symptoms in schizophrenic syndromes, Wciórka and co-workers took into account self as one of the dimensions, including: the sense of depersonalization, sense of self-incoherence, sense of selfnonidentity [50]. Unlike many widely used and internationally recognized schizophrenic symptomatological scales such as BPRS [51], SAPS [52], SANS [53], PANSS [54], the authors of KOZS were the first to highlight the importance of disorders of self in schizophrenia, extending the area of clinical judgment by this aspect.

\subsection{Marek Nieznański's findings regarding disorders of self in schizophrenia $(2003,2004)$}

Nieznański [55] studied the relationships between the formal properties of the structure of self and the efficiency of reality monitoring in schizophrenia patients. Reality monitoring in cognitive psychology consists in distinguishing an internal source from the external source of information. In his study, the author validated the hypothesis assuming that the difficulty in identifying one's own identity by patients with schizophrenia may be related to inability to accurately assess whether the stimulus was previously produced by self or no-self. The study examined the structure of the self in 41 people diagnosed with schizophrenia in a stable mental state by extracting the following main measures describing the formal properties of the structure of self: a sense of stability of self in time, the degree of distinctiveness of self structure, stability and separateness of self schema, and differentiation of self-image.

For this purpose, a list of 50 human traits developed by Lewicka [56] was used, and the method of evaluating the properties of the self structure was borrowed from 
research tools based on the cognitive concept of identity and developed by Jarymowicz [57].

It was shown that the basic properties of the self structure were significantly related to the types of errors in reality monitoring. Patients whose self-image was poorly defined or significantly concordant with other people's image (who chose only a few features or listed almost all adjectives on the list) were inclined to assimilate as their own information that did not actually come from them. Patients in whom large discrepancies between self-image and "self-in-the-past" or lack of stability of self were noticed, significantly more often mistakenly attributed their own words to external sources. The results obtained by the author indicate that there is a correlation between the level of developing self structure and their ability to identify their own cognitive activity, and that one of the mechanisms of blurring of distinction between self and environment are errors in reality monitoring.

In another study of the basic features of the self schema in schizophrenia, the author points out that patients, in comparison to healthy individuals have a greater sense of personality change over time and a lower level of self-others schema distinctiveness [58].

\subsection{Mirosława Huflejt-Łukasik's findings on self dis- order in schizophrenia (2010)}

Huflejt-Łukasik [1] in the work „Self and selfregulation processes" presented the results of her research on identity, self-evaluation, self-regulation and, in this context, the differences between healthy people and patients with mental disorders, including schizophrenia. The results indicate that the basic variables of the author's concept, i.e. the clarity of the image of self, the features of the ideal structure of self, auto-focus and selfevaluation appear to reflect important aspects of self and self-regulation processes that determine the differences between mental health and mental disorders. The less clear picture of one's self-image and the less hierarchical and more rigid structure of ideal self, the greater the autofocus, especially the focus on the private self. Less clear self-image and greater auto-focus are associated with lower self-evaluation.

The author has shown that people with psychiatric disorders, including schizophrenia, perceive themselves, their own self as less clear and firmly defined, less stable internally and less stable in time. In this work she also analyzed the structure of the ideal self, which turned out to be less flexible in people with mental disorders, including those with schizophrenia, which was associated with high levels of anxiety. The features of the rigid structure of the ideal self, such as greater power of interconnections between standards of self, lower diversity and hierarchy of their structure, serve to protect schizophrenia patients from undesirable changes within the ideal self. On the other hand, such phenomena increase auto-focus, resulting in disturbed self-regulation.

\section{Conclusions}

The presentation of different findings and concepts of self in relation to schizophrenia can be seen a valuable contribution, adding to the literature on the essence of this disorder. It is planned to include the self disorder as one of the diagnostic criteria for schizophrenia in the current ICD-11 classification [59]. Recently, there has been a renaissance of phenomenological approach in the study of schizophrenia. This may be proof that contemporary psychiatric classifications, based on the Schneiderian approach, have exhausted their potential as a tool for the accurate identification of patients on the one hand, and on the other hand, for understanding patients' experiences and finding the best form of therapy for them.

The findings and views of Polish authors on this issue presented in this article provide an interesting, although not well known in the world, contribution to research on schizophrenia disorders. There is hope for further development of research on self disorders in schizophrenia in the context of, among others, the search for the biological basis of observed disorders, the possibilities for early intervention, improved insight into illness, or the development of forms of psychotherapy aimed at bringing the self to the central position in communication with oneself and the world.

\section{Wstęp}

Określona ukształtowana tożsamość jest fundamentem funkcjonowania psychicznego człowieka [1]. Poczucie własnego istnienia jako jednostki $[2,3,4]$ razem z uświadomionym obrazem własnej osoby pełni podstawową rolę w regulacji zachowań [1].

Określane w literaturze przedmiotu jako „poczucie własnego ja” czy też „poczucie własnej tożsamości”, wydaje się być oczywistym przymiotem człowieka i dlatego jego zaburzenia zostały szeroko opisane przez teorety- ków osobowości [5], jak i psychiatrów [6, 7]. Problematyka ta była omawiana $\mathrm{w}$ odniesieniu do genezy takich zaburzeń jak zaburzenia osobowości, nerwice czy zespoły depresyjne $[4,7,8,9]$, jednak szczególnie ciekawe wydaje się być przeanalizowanie zaburzeń Ja występujących w przebiegu schizofrenii, które to według niektórych autorów $[6,10,11,12]$ stanowią jej istotę.

Już w latach siedemdziesiątych prowadzono w Polsce badania dotyczące zaburzeń $J a$ w schizofrenii $[6,13,14]$. Należy podkreślić, że po zakończeniu II wojny światowej 
Polska, wskutek uzgodnień aliantów w Jałcie, znalazła się za „żelazną kurtyną”, w strefie wpływów sowieckich aż do roku 1989 [15]. Ograniczenie kontaktów ze światową nauką w znacznym stopniu utrudniało wymianę myśli naukowej, wskutek czego prace polskich autorów z tamtego okresu rzadko były znane za zachodnią granicą Polski.

Celem niniejszego artykułu jest przedstawienie wkładu polskich badaczy (psychiatrów i psychologów) w rozumienie zjawiska poczucia $J a$, tożsamości i ich zaburzeń, ze szczególnym uwzględnieniem schizofrenii.

\section{Metoda}

Dokonano przeglądu dostępnej literatury polskich autorów dotyczącej poruszanej problematyki, korzystając z baz danych: Polskiej Bibliografii Lekarskiej, CEJS, NUKAT oraz Bazy Biblioteki Narodowej, używając słów kluczowych: Ja, tożsamość, self, jaźń, schizofrenia, osobowość oraz deskryptorów czasowych: 1970-maj 2017. W artykule uwzględniono jedynie te prace, które stanowiły oryginalny wkład polskich autorów do badań nad zagadnieniem Ja i poczucia tożsamości, ze szczególnym uwzględnieniem ich zaburzeń w przebiegu schizofrenii.

Celem przejrzystości artykuł podzielono na następujące części:

1. Podstawowe pojęcia i teorie dotyczące zagadnienia Ja i tożsamości

2. Koncepcje trzech polskich autorów dotyczące zagadnienia Ja i tożsamości:

2.1 Janusza Reykowskiego (1975)

2.2 Józefa Kozieleckiego (1986)

2.3 Zbigniewa Zaborowskiego (1989)

3. Ja oraz tożsamość $\mathrm{w}$ aspekcie klinicznym ze szczególnym uwzględnieniem zaburzeń Ja w przebiegu schizofrenii w badaniach polskich autorów:

3.1. Antoniego Kępińskiego (1972)

3.2. Jerzego Zadęckiego (1972, 2013)

3.3. Małgorzaty Rzewuskiej (1988)

3.4. Stanisławy Steuden (1997)

3.5. Jacka Wciórki (1997)

3.6. Marka Nieznańskiego $(2003,2004)$

3.7. Mirosławy Huflejt-Łukasik (2010)

4. Podsumowanie

\section{Podstawowe pojęcia i teorie dotyczące zagadnienia Ja i tożsamości}

Pojęcia Ja (self) oraz tożsamość (identity) - dosyć często używane są zamiennie, przy czym każde $\mathrm{z}$ nich może mieć wiele definicji [1].

W literaturze przedmiotu - oprócz wymienionych wspomnianych wyżej terminów poczucia Ja oraz poczucia tożsamości - funkcjonują jeszcze inne określenia powiązane z omawianym zagadnieniem, takie jak: samowiedza [5, 16], system modeli i wizji pojęciowych dotyczących własnej osoby [2], reprezentacja poznawcza własnej osoby [5], czy samoświadomość [17].

Wielu autorów w swoich pracach $[1,18]$, dotyczących Ja sięga do dziewiętnastowiecznej koncepcji self Jamesa [19], który jako pierwszy wprowadził podział na self „podmiotowy” (poznający) i self „przedmiotowy” (będący przedmiotem poznania) [1, 19, 20]. Koncept ten został potem rozbudowany przez fenomenologiczną szkołę Rogersa [4].

W ujęciu Rogersa świadoma reprezentacja własnego istnienia i funkcjonowania rozwija się w interakcji z ważnymi dla nas ludźmi, tworząc obraz Ja, który składa się z naszych spostrzeżeń dotyczących charakterystycznych aspektów własnej osoby, naszych relacji z innymi i ze światem $[21,22]$.

Obecnie termin Ja jest używany w szerszym znaczeniu i obejmuje: przeżycia danej osoby, jej subiektywny odbiór samej siebie - jej spostrzeżenia, myśli, uczucia na własny temat, oraz wysiłki podejmowane w celu kierowania, regulowania własnym zachowaniem $[1,23]$.

Inni autorzy co prawda łączą pojęcia Ja i tożsamości - jednak nie są dla nich synonimami [24, 25, 26]. Tożsamość uważana jest przez tych autorów za reprezentację poznawczą, dynamiczny wyraz procesów samoświadomości uwarunkowanych określoną strukturą osobowości, a zwłaszcza strukturą $J a$.

Jeszcze inaczej zależność obu pojęć przedstawili Płużek [27] oraz Chlewiński i Grzywa [28], traktując tożsamość jako synonim Ja podmiotowego, a obraz siebie jako synonim Ja przedmiotowego.

W literaturze przedmiotu tożsamość oraz poczucie Ja funkcjonuje jeszcze w dwóch innych aspektach: jako tożsamość osobista [1], obejmująca świadomość siebie, własną spójność w czasie i przestrzeni, a jednocześnie świadomość własnej odrębności i niepowtarzalności [5] oraz tożsamość społeczna - wyrażająca relacje z innymi ludźmi oraz przynależność do grup społecznych [29].

Formowanie się struktury Ja oraz poczucia tożsamości w rozwoju ontologicznym człowieka. Człowiek po urodzeniu nie ma poczucia egzystencji jako jednostki odrębnej od reszty świata - jest to faza symbiozy. Zgodnie z teorią relacji z obiektem, następna faza rozwoju osobniczego - faza separacji to wieloetapowe stadium, w którym dziecko zdobywa poczucie odrębności [30, 31].

Umiejętność dostrzeżenia granic własnego ciała stanowi wielki przełom w rozwoju człowieka, gdyż umożliwia pojawienie się globalnego poczucia $J a$, a to stanowi podstawę procesu dookreślania własnej tożsamości [29, 32]. 
Doświadczenie bycia sobą oznacza, że przeżywamy życie z perspektywy pierwszej osoby, jako Ja teraźniejsze, w liczbie pojedynczej, czasowo trwałe, cielesne. Josef Parnas opierając się na spojrzeniu fenomenologicznym używa pojęcia tzw. minimalnego (bazalnego) self, odnoszącego się do wypowiadania doświadczeń w pierwszej osobie. W trakcie rozwoju osobniczego na minimalny self nakładają się bardziej złożone struktury, które ostatecznie składają się na to, co nazywamy tożsamością jednostki. Minimalne self wiąże się też z automatycznym przeżywaniem świata, w którym znajduje się jednostka. Świat jest pojmowany domyślnie, traktowany jako oczywiste tło wszystkich doświadczeń. Taki odbiór otaczającego świata jest naturalną cechą ontologiczną człowieka [33].

U podłoża spostrzegania świata „Z własnej perspektywy" leży wiele mechanizmów. Wczesna forma to tzw. poznawcze generalizowanie własnych doświadczeń, preferencji, przekonań, które bierze się z poczucia, że inni są podobni do Ja. Później pojawiają się zniekształcenia w percepcji siebie i świata o charakterze egotystycznym by podtrzymać dobre mniemanie o sobie, by można było zachować poczucie własnej wartości [29].

$\mathrm{W}$ toku ontogenezy formują się określone potrzeby Ja, których niezaspokojenie prowadzi do naruszenia równowagi funkcjonalnej $\mathrm{w}$ obrazie własnej osoby, a tym samym w całym procesie regulacji [3].

Eriksonowski kryzys tożsamości okresu dojrzewania i wczesnej dojrzałości stanowi również ważny etap w kształtowaniu się tożsamości [30, 34].

Ideał własnego Ja realizuje się rzadko, gdyż jest to proces bardzo skomplikowany, natomiast pewien dysonans między realnym a idealnym obrazem własnej osoby jest konieczny dla prawidłowego rozwoju osobowości człowieka, który dzięki niezadowoleniu z siebie może wciąż się zmieniać i doskonalić [4, 9].

\section{Koncepcje Janusza Reykowskiego, Józefa Kozielec- kiego oraz Zbigniewa Zaborowskiego dotyczące za- gadnień Ja i tożsamości}

W tym miejscu należy odwołać się do prac trzech polskich autorów - Reykowskiego, Kozieleckiego oraz Zaborowskiego. Ich koncepcje stanowią ciekawe uzupełnienie wiedzy dotyczącej poczucia Ja oraz tożsamości.

\subsection{Koncepcja Janusza Reykowskiego (1975)}

Według Reykowskiego, autora regulacyjnej teorii osobowości, istnieją trzy podstawowe potrzeby Ja: potrzeba zachowania tożsamości (t). integralności Ja), potrzeba zachowania własnej wartości i potrzeba zachowania kontroli nad otoczeniem $[3,5]$.

Potrzeby te są ściśle ze sobą związane, a przejawiają się mniejszym lub większym zapotrzebowaniem na tzw. informacje podtrzymujące. Informacje podtrzymujące mają na celu potwierdzenie poczucia tożsamości, własnej wartości i kontroli. Zapotrzebowanie na informacje podtrzymujące zależy od stopnia rozwoju obrazu własnej osoby. Brak lub niedobór informacji potwierdzających obraz własnej osoby stanowi sytuację zagrożenia dla Ja, która doprowadza do nadmiernej koncentracji na sobie (egocentryzm), w której jedynym punktem odniesienia dla działania jednostki staje się własna osoba $[18,35,36]$.

\subsection{Koncepcja Józefa Kozieleckiego (1986)}

Popularność zdobyła również teoria samowiedzy Kozieleckiego. Samowiedza jest strukturą złożoną, na którą składają się sądy opisowe i wartościujące, standardy osobiste oraz reguły generowania oraz komunikowania wiedzy o sobie. Samowiedzę mogą charakteryzować różnorodne sprzeczności, których liczba i nasilenie są zależne od wielu czynników. Sprzeczności te utrudniają przystosowanie się do rzeczywistości i uniemożliwiają racjonalne działanie, co może znajdować odzwierciedlenie w pojawieniu się objawów i zespołów psychopatologicznych [16, 18].

\subsection{Koncepcja Zbigniewa Zaborowskiego (1989)}

Zbigniew Zaborowski jest autorem teorii treści i form samoświadomości [17, 24]. Treścią samoświadomości mogą być dane percepcyjne, myśli, sądy, uczucia, pragnienia, plany, zachowania jednostki, pełnione przez nią role, stosunki społeczne itd. Nie funkcjonują one w sposób dowolny, przypadkowy czy też chaotyczny. Porządek do ich funkcjonowania wprowadzają formy samoświadomości [37].

Zaborowski wyróżnia cztery formy samoświadomości: indywidualną, zewnętrzną, obronną i refleksyjną. Samoświadomość indywidualna łączy się z personalnym, emocjonalnym przetwarzaniem treści na podłożu struktury Ja. Jednostka z samoświadomością indywidualną sama planuje i programuje swoje cele i zadania, identyfikuje się z nimi, silnie przeżywa emocje, dokonuje osobistych atrybucji. Osoby o wyższej samoświadomości indywidualnej są na ogół egocentryczne, introwertywne, przejawiają często poczucie kontroli wewnętrznej. Samoświadomość obronna z kolei łączy się z kodowaniem i przetwarzaniem treści wewnętrznych i zewnętrznych na podłożu lęku i zagrożenia. Osoby przejawiające tę formę są silnie skoncentrowane na sobie. Samoświadomość obronna pojawia się $\mathrm{w}$ warunkach doświadczenia stresu, niepowodzenia, w związku z nerwicą, chorobą fizyczną czy psychiczną. Samoświadomość zewnętrzna polega na kodowaniu i przetwarzaniu treści w sposób obiektywny, uspołeczniony. Opiera się ona na normach i standardach społecznych. Jednostka wyzbywa się niekiedy subiektywizmu i swoje relacje z innymi i światem oraz swoje przeżycia traktuje bezstronnie, w sposób przedmiotowy. Samo- 
świadomość zewnętrzna ułatwia sprawną realizację zadań, sprzyja efektywnej współpracy i przystosowaniu społecznemu. Samoświadomość refleksyjna charakteryzuje się uogólnionym, abstrakcyjnym przetwarzaniem treści, integracją informacji wewnętrznych z zewnętrznymi, przy czym są to informacje przeważnie typu semantycznego. Jest to najwyższa forma samoświadomości, umożliwiająca efektywną samoregulację, samorealizację i twórcze przystosowanie się do środowiska [17, 24].

\section{Ja oraz tożsamość $w$ aspekcie klinicznym ze szcze- gólnym uwzględnieniem zaburzeń Ja w przebiegu schizofrenii $w$ badaniach polskich autorów}

W wyniku przejścia przez kolejne fazy rozwojowe ludzie różnią się stopniem, w jakim osiągnęli poczucie tożsamości wyrażające się odrębnością od otoczenia oraz wewnętrzną spójnością. Różnią się też stopniem fiksacji na wczesnym stadium rozwoju lub regresji do tych stadiów. Ta fiksacja i regresja decydują o patologii poczucia tożsamości [30].

Wcześniejsze doświadczenia, które ukształtowały Ja, wpływają na funkcjonowanie osoby i jej podatność na zaburzenia psychiczne [1].

Zaburzenia tożsamości są rozpatrywane albo na podstawie tego, co pacjent odczuwa i relacjonuje, albo na podstawie rozbieżności pomiędzy tym, co dana osoba twierdzi a stanem faktycznym, np. że jest inną osobą. Odnośnie tego, co dana osoba odczuwa i relacjonuje, można wyróżnić bardzo wiele elementów, które mogą zostać zakłócone w różnych zaburzeniach psychicznych [1].

Sokolik [30] np. wyróżnia sześć typów zaburzeń tożsamości:

1. Poczucie utraty granic między sobą lub otoczeniem, poczucie zatracania samego siebie

2. Brak wewnętrznej treści, poczucie pustki, bezsensu życia

3. Brak orientacji, wiedzy, kim się jest

4. Brak poczucia ciągłości ze sobą z przeszłości, nierozpoznawanie siebie, poczucie obcości samego siebie, które może dotyczyć całej osoby lub tylko aspektów fizycznych czy psychicznych

5. Poczucie rozbicia Ja na części, czyli brak lub utrata wewnętrznej spójności, w tym także podział na psychikę i ciało, bycie wewnętrznym obserwatorem i ukrywanie prawdziwego Ja w obawie przed tym, że inni je zniszczą

6. Poczucie nierzeczywistości własnego istnienia, jego braku, wrażenie że się jest nierzeczywistym, nieżywym.

Do zaburzeń tożsamości odnoszono się $\mathrm{w}$ kontekście wielu zaburzeń psychicznych [4, 6, 7, 8, 9], na szczególną uwagę zasługuje problematyka zaburzeń $J a \mathrm{w}$ przebiegu psychoz schizofrenicznych. Temat ten, mimo że podejmowany w pracach takich klasyków psychiatrii jak Min- kowski [38] czy Jaspers [39], przez wiele lat był poza głównym nurtem badań nad schizofrenią.

\subsection{Poglądy Antoniego Kępińskiego na zaburzenia Ja w schizofrenii (1972)}

Na polskim gruncie do rozumienia problematyki zaburzeń Ja w schizofrenii przyczyniły się przede wszystkim prace Antoniego Kępińskiego [6, 40, 41].

Kępiński, twórca oryginalnej koncepcji metabolizmu informacyjnego człowieka, wyróżniał 3 zasadnicze elementy w świecie przeżyć:

1. Ja, które stanowi punkt centralny

2. Granica, która oddziela świat wewnętrzny od zewnętrznego

3. Swoisty porządek przestrzenno-czasowy, według którego układają się przeżycia.

Poza porządkiem czasowo-przestrzennym ważną rolę w subiektywnym odczuciu odgrywa porządek wartościujący (hierarchia wartości) [41].

Poprzez wspomnianą granicę odbywa się metabolizm informacyjny ustroju ze światem zewnętrznym $[42,43]$.

Dzieła Kępińskiego pt. „Schizofrenia” [6], „Melancholia" [9] i „Lęk" [44] stanowią trwały wkład w piśmiennictwo światowe z zakresu psychiatrii fenomenologicznoantropologicznej [41].

Autor dużo miejsca poświęcił analizie czasowości i przestrzenności, a szczególnie kategorii czasoprzestrzeni, będącej rezultatem przeniesienia na grunt fenomenologii implikacji teorii względności. Według niego, stopień ekspansji czasoprzestrzeni stanowi miarę ewolucji, przy czym zachodzi tu zależność wprost proporcjonalna: im wyższy poziom rozwoju, tym szersza czasoprzestrzeń, np. dzięki ruchowi i aktywności istoty żywe rozszerzają swą czasoprzestrzeń $[6,41]$.

Kępiński wyodrębniał kilka rodzajów przestrzeni fenomenologicznej, np. przestrzeń życiową, przestrzeń indywidualną i wspólną, przestrzeń wolną i ograniczoną, przestrzeń otwartą i zamkniętą, przestrzeń rzeczywistą i przeżywaną [6, 41, 44].

Podkreślał on współzależność czasoprzestrzeni, uczuć i nastroju. Akcentował także swoiste własności doświadczanej przestrzenności, jak jej niejednorodność i zmienność. Przestrzeń życiowa, która według terminologii używanej przez Kępińskiego obejmuje zakresowo wszystkie pozostałe formy przestrzenności, powinna umożliwiać człowiekowi samorealizację. Ograniczenie tej przestrzeni jest równoznaczne z ograniczeniem możliwości rozwoju człowieka [41].

Podstawą koncepcji psychopatologicznych Kępińskiego jest analiza i opis patologii w zakresie wszystkich wymienionych atrybutów świata fenomenologicznego. W kategoriach patologii Ja, patologii granicy, zaburzeń porządku czasowo-przestrzennego i zaburzeń hierarchii 
wartości, rozpatrywał strukturę świata psychotycznego, zwłaszcza w schizofrenii i melancholii [6, 9, 41, 42]. Jego zdaniem, psychoza schizofreniczna przejawia się głównie w postaci patologii granicy oraz patologii Ja.

Patologia granicy wyraża się $\mathrm{w}$ formie autyzmu oraz rozbicia (pęknięcia) granicy między światem wewnętrznym a zewnętrznym, w wyniku czego dochodzi do tworzenia się urojeń, omamów, projekcji i introjekcji uczuciowej, tranzytywizmu, automatyzmu psychicznego, czy też np. poczucia wszechmocy.

Z kolei wyrazem patologii Ja w schizofrenii według Kępińskiego są między innymi: brak wolności $J a$, utrata zdolności do integracji, zachwianie poczucia rzeczywistości własnego Ja (stąd np. depersonalizacja, derealizacja), utrata tożsamości, zmiana obrazu samego siebie, rozszczepienie $J a$, rozbicie $J a$, czy też krystalizacja rozbitego Ja $\mathrm{w}$ urojonej roli $[6,41]$.

Opisanym zmianom towarzyszy jednocześnie patologia porządku czasowo-przestrzennego (np. „zatrzymanie się" czasu, rozerwanie ciągłości czasu, swoboda poruszania się w przestrzeni, „pęcznienie $J a^{\prime}$, , „pulsowanie $J a^{\prime \prime}$ oraz utrata porządku wartościującego) [6, 41].

Najbardziej charakterystycznym według Kępińskiego objawem schizofrenii jest zakłócenie współrzędnych przestrzennych - zbliżenie otaczającego świata, czyli fizjognomizacja. Termin ten według psychiatrii egzystencjalnej oznacza sytuację, w której świat otaczający naciska na chorego tak jakby on tylko był na świecie, wszystko ma jakieś znaczenie. Bywa też odwrotnie, że świat otaczający oddala się od chorego, zaczyna otaczać go pustka i nicość, nic się wokół nie dzieje, nic go nie dotyczy. Czasem chory odczuwa jakby raz otaczający świat zbliżał się za bardzo, to znów oddalał [41].

\subsection{Wyniki badań i poglądy Jerzego Zadęckiego na zaburzenia Ja w schizofrenii $(1972,2013)$}

Niezwykle ambitnego zadania podjął się w latach 1968-1972 Jerzy Zadęcki w ramach badań do swojej pracy doktorskiej pt. „Zaburzenia życia uczuciowego we wczesnej schizofrenii, czyli o dążeniach, intencjach, wartościach, obrazie siebie i relacjach $\mathrm{z}$ innymi" [13, 14]. W oparciu o metodę analizy fenomenologicznej badał życie uczuciowe pacjentów z rozpoznaniem schizofrenii. Jak wspomina autor, wybrany przez niego sposób pracy naukowej, oparty na opisie subiektywnego doświadczenia pacjentów, nie zyskał początkowo dużego zainteresowania i przychylności ze względu na jego odmienność od powszechnie przyjętego paradygmatu nauk przyrodniczych [14]. Promotorem pracy był sam profesor Antoni Kępiński, któremu przedwczesna śmierć uniemożliwiła uczestnictwo w obronie pracy swojego doktoranta.

Autor dokonał analizy fenomenologicznej narracji aż 60 pacjentów, co jest ze względu na wielkość badanej grupy zjawiskiem bez precedensu. Zazwyczaj badania tego typu opierają się na modelu Binswangera (analiza wypowiedzi jednej osoby) lub obejmują 4-25 osób [45]. Początkowo analiza poświęcona była, zgodnie z tytułem jego pracy doktorskiej, uczuciom przeżywanym przez pacjentów w odniesieniu do kryzysu realności, współrzędnej czasu, współrzędnej wartości, dezintegracji uczuć. Po wielu latach, na fali renesansu fenomenologii egzystencjalnej w psychiatrii, autor dokonał ponownej interpretacji swoich wcześniejszych spostrzeżeń i zidentyfikował siedem form zaburzeń Ja we wczesnej schizofrenii, które w języku Heideggera odpowiadają Dasain, czyli formom bycia-w-świecie [46]. Każdej kategorii odpowiadał charakterystyczny styl egzystencji (modus vivendi) z należącymi do tej kategorii dążeniami, uczuciami, wartościami, doświadczeniami ciała, doświadczeniami innych.

1. La słabe i zależne - podporządkowujące się autorytetom, charakteryzujące się brakiem spontaniczności i ubóstwem ekspresji oraz brakiem własnej opinii i inicjatywy. Doświadczeniu Ja towarzyszy uczucie skrępowania, wstydu, poczucia zastoju, ukrywane przed otoczeniem. Impas związany z brakiem inicjatywy jest najbardziej widoczny poza środowiskiem rodzinnym w konfrontacji z nowymi zadaniami.

2. Konsolidacja Ja wokół dążeń duchowych - kiedy to cała uwaga pacjenta jest zogniskowana na określonej aktywności poszukiwania sposobu rozwiązania poczucia napięcia, lęku lub uczucia pustki. Poszukiwanie prawdy: „jakim jestem, kim są naprawdę inni ludzie”, często wiąże się z nasileniem np. twórczości artystycznej czy praktyk religijnych, którym towarzyszy uczucie kontaktu z innymi i samym sobą w obecności Boga, opisywanym w doświadczeniach mistycznych. W momencie przerwania lub zahamowania tych aktywności pacjenci nie są w stanie zwykle podjąć żadnej innej aktywności.

3. Doświadczenie dezorientacji Ja - gdy wzmożonej aktywności pacjentów towarzyszy dezorientacja co do celów i wartości. Decyzje życiowe są podejmowane w sposób niewystarczający, podyktowany często raptowną zmianą nastawienia uczuciowego, połączonego $\mathrm{z}$ utratą Ja jako trwałego punktu odniesienia w czasie i przestrzeni. Chaos dotyczy nie tylko decyzji życiowych, ale także uczuć, co pociąga za sobą brak zobowiązań, w skrajnych przypadkach absolutny relatywizm w zakresie wartości. Pacjenci mają trudność w ustaleniu swojej tożsamości w stosunku do zbiorowości w historycznym sensie, a także w stosunku do zobowiązań, których podjęli się wobec innych, tłumacząc to stwierdzeniem „nie wiem kim jestem”.

4. Doświadczenie maski Ja - doświadczenie Ja jako nieprawdziwego i sztucznego. Doświadczanie maski we wczesnej schizofrenii jest związane z utratą jej funkcji 
instrumentalnej, umożliwiającej komunikację $\mathrm{z}$ otoczeniem i jest odbierane przez otoczenie jako zahamowanie. Pęknięcie maski wiąże się $\mathrm{z}$ nagłym uwolnieniem wewnętrznych przeżyć, ukrywanych kompleksów uczuciowych, najczęściej wobec rodziców, w formie bezładnych zdań. Konsekwencje sprowadzają się do trudności w inicjowaniu i podtrzymaniu kontaktów społecznych, codziennym funkcjonowaniu, utracie taktu i niuansów właściwym kontaktom społecznym.

5. Doświadczenie utraty $J a-w$ konsekwencji nieoczekiwanych wydarzeń, porażki w drodze do celu, utraty maski, z reguły w sytuacjach przejęcia całkowitej kontroli przez innych, braku intymnego kontaktu z własnym ciałem dochodzi do doświadczenia utraty Ja. Pacjenci z pozycji idealnego obserwatora opisują doświadczenia depersonalizacji, braku uczuć, lub całkowicie zaprzeczają swojej egzystencji ,ja nie istnieję".

6. Rzekoma realizacja Ja - w wyobraźni, kiedy subiektywne doświadczanie przysłania racjonalne opracowywanie wydarzeń. $\mathrm{W}$ okresie prodromalnym pragmatyczna ocena stopniowo zostaje zastąpiona subiektywnym doświadczeniem, które ostatecznie prowadzi do kreowania swojej własnej, „mojej własnej” (łac. solum ipsem) subiektywnej realności. Na dalszym etapie choroby, w momencie krystalizacji urojeń, doświadczenie subiektywne całkowicie dominuje nad doświadczaniem realnym.

7. Nabyta identyfikacja Ja - poszukiwanie prawdy łączy się z utratą pewności co do własnych celów i wartości, którymi należy się kierować. Stopniowo następuje krystalizacja urojeń identyfikacji z uczuciem egzaltacji, poczucie bycia wybranym. Zdaniom oznajmującym np. „Jestem drugim Newtonem" towarzyszy doświadczenie rzekomej samorealizacji i wiąże się z zaniechaniem praktycznej działalności [14].

Autor zwraca uwagę, iż istota i znaczenie opisanych zaburzeń $J a$, może nie być wcale oczywista we wczesnej fazie schizofrenii, gdyż transformacja, reorganizacja Ja i rozwój zaburzeń mogą być rozciągnięte w czasie.

Należy podkreślić, że wyniki pracy J. Zadęckiego stały się też kanwą dla jednej z form psychoterapii prowadzonej $\mathrm{w}$ psychoterapeutycznie zorientowanym programie środowiskowym $\mathrm{w}$ ośrodkach psychiatrii środowiskowej w Krakowie [47]. Wybrane fragmenty pracy są przez pacjentów po ustąpieniu ostrych objawów psychotycznych komentowane lub są przedmiotem ich refleksji $\mathrm{w}$ kontekście indywidualnym albo grupowym. Praktyka ta wynikła z potrzeby sygnalizowanej przez pacjentów, zrozumienia tych doświadczeń, które prowadziły do hospitalizacji i nosiły zagadkowy dla nich i otoczenia charakter. Proces uzyskiwania wglądu w tym wypadku polega $\mathrm{z}$ jednej strony na identyfikacji różnych przeżyć $\mathrm{w}$ analizowanym materiale, $\mathrm{z}$ drugiej na obserwacji ich występowania u siebie.
Narracyjna konstrukcja, jaką pacjent opracowuje $\mathrm{w}$ wyniku refleksji nad materiałem fenomenologicznym zgromadzonym w pracy, pozwala na wzmocnienie lub rekonstrukcję własnego $J a$, a przez to odtworzenie dążeń, hierarchii wartości i celów życiowych, które mają szansę na realizację [14].

\subsection{Wyniki badań Małgorzaty Rzewuskiej uwzględ- niające zaburzenia Ja w schizofrenii (1988)}

Rzewuska [48], przy użyciu polskiej wersji kwestionariusza EPP (Ego-Psychopathology), Christiana Scharfettera poszukiwała związków pomiędzy zaburzeniami postrzegania własnej osoby a przebiegiem choroby w grupie 185 pacjentów cierpiących na schizofrenię. Zastosowany $\mathrm{w}$ badaniu kwestionariusz EPP służy do oceny pięciu aspektów patologii ego: zaburzenia tożsamości (stałości i trwałości siebie w różnych warunkach i upływającym czasie), aktywności (autorstwo własnych przeżyć i zachowań), witalności (poczucie własnej żywotności), spójności (integralności siebie) i rozgraniczenia (ostrości granic pomiędzy sobą a otoczeniem) [49].

Wyniki uzyskane przez badaczkę [48] skłoniły ją do podziału psychoz schizofrenicznych na trzy grupy:

I. grupę utworzyło 25\% badanych, u których obserwowano powolny rozwój choroby, a obszar treści wytwórczych w przebiegu choroby poszerzał się. W grupie tej proces częściowej dezintegracji, określanej jako rozrastanie, osłabiał spójność pomiędzy podsystema$\mathrm{mi}$, ale pozwalał na tworzenie nowych powiązań. W obrazie treści wytwórczych stwierdzano pewną ich strukturalizację (powiązania między prześladowcami, częste dialogi omamów, urojeniowe poznawanie otoczenia). Dezintegracja funkcji osobowości (jako całości) powodowała często formalne zaburzenia myślenia, wyraźne pogorszenie przystosowania społecznego. W trakcie nawrotów choroby, narastały u badanych zaburzenia spójności, tożsamości i witalności. Częste pojawiania się $\mathrm{w}$ treściach wytwórczych niezrozumiałej symboliki przemawia za tym, że ten rodzaj dezintegracji wiąże się z „przesunięciem” własnych przeżyć do przestrzeni oceny otoczenia.

II. grupę utworzyło $35 \%$ badanych, u których treści wytwórcze stale koncentrowały się wokół nich samych. W grupie tej choroba zaczynała się ostro, a jej nawroty były liczne. Dezintegracja w tej grupie była najsilniej wyrażona, osobowość chorych uległa „rozkładowi”. Najwyraźniejsze były tu objawy negatywne. Silne powiązanie objawów z własną osobą (depersonalizacja, urojenia hipochondryczne) przemawia za tym, że w procesie dezintegracyjnym chorzy przenoszą zdarzenia dotyczące relacji $\mathrm{z}$ otoczeniem $\mathrm{w}$ wewnętrzną przestrzeń samooceny. 
III. grupe stanowiło $40 \%$ badanych, u których objawy stale wiązały się z rzeczywistym otoczeniem. Przystosowanie społeczne tych chorych było dość dobre, poprawy często długie, początek choroby późny. Zaburzenia tożsamości i spójności z otoczeniem notowano rzadziej, natomiast często stwierdzano poczucie zatarcia granicy Ja-otoczenie.

Autorka sugerowała, że taki podział psychoz na trzy grupy umożliwia stosowanie bardziej celowanych interwencji terapeutycznych $\mathrm{w}$ tak niejednorodnej grupie pacjentów $\mathrm{z}$ rozpoznaną schizofrenią, np. $\mathrm{u}$ chorych $\mathrm{z}$ nasiloną dezintegracją - celowa wydaje się długotrwała farmakoterapia, u badanych $\mathrm{z}$ silnymi mechanizmami integracyjnymi - ukierunkowanie oddziaływań psychoterapeutycznych na poprawę ostrości granicy Ja-otoczenie, przy dyskusyjnym podawaniu długoterminowym leków przeciwpsychotycznych w tej grupie pacjentów.

\subsection{Wyniki badań Stanisławy Steuden dotyczące za- burzenia Ja w schizofrenii (1997)}

Steuden w ramach badań przeprowadzanych do rozprawy habilitacyjnej zatytułowanej „Dynamika zmian osobowości u osób z rozpoznaną schizofrenią” oceniała dynamikę koncepcji Ja oraz subiektywne poczucie zmiany osobowości u pacjentów $\mathrm{w}$ rozpoznaną schizofrenią $\mathrm{w}$ trakcie piętnastoletniego okresu obserwacji [18]. Najbardziej intensywne zmiany osobowości stwierdzono w pierwszym okresie choroby. Dotyczyło to m. in. postawy lękowej, poczucia inności, obcości i niezrozumienia. We wszystkich badaniach (na początku i po kilkunastu latach choroby) u większości chorych stwierdzono zaburzone poczucie własnej tożsamości. Pacjenci posiadali niejasną koncepcję siebie, poczucie istnienia konfliktu pomiędzy różnymi obszarami percepcji i przedstawiania siebie, obserwowano także brak integracji pomiędzy zewnętrznymi i wewnętrznymi wymiarami Ja. Z czasem występowała względna stabilność odnośnie zaburzeń tożsamości u badanych. Zaburzone poczucie własnej tożsamości wiązało się z brakiem poczucia ciągłości własnego Ja (chory ma poczucie, że nie jest tym, kim był dotychczas) i przynależności (zaburzenia w ustalaniu tego, kim się jest w relacji do swojej rodziny, grupy społecznej czy zawodowej). Ponadto, co ciekawe, autorka wykazała, iż największe różnice pomiędzy grupą mężczyzn i kobiet, zarówno z uwagi na zakres, jak i nasilenie zaburzeń poczucia własnej tożsamości, występowały w trzech pierwszych miesiącach, zacierając się po kilkunastu latach trwania choroby [18].

\subsection{Poglądy Jacka Wciórki na miejsce zaburzenia Ja w schizofrenii (1997)}

Wciórka i współpracownicy, konstruując autorską skalę Klinicznej Oceny Zespołu Schizofrenicznego (KOZS), służącą do klinicznej oceny objawów psychopatologicz- nych występujących w zespołach schizofrenicznych, uwzględnili jako jeden z wymiarów jaźń, obejmujący: poczucie obcości siebie, poczucie niespójności siebie, poczucie nietożsamości siebie [50]. W przeciwieństwie do wielu szeroko stosowanych i uznanych na świecie skal oceniających symptomatologię schizofreniczną, np. BPRS [51], SAPS [52], SANS [53], PANSS [54], autorzy skali jako pierwsi zwrócili uwagę na istotne znaczenie zaburzeń Ja w schizofrenii, poszerzając o ten aspekt obszar oceny klinicznej.

\subsection{Wyniki badań Marka Nieznańskiego uwzględnia- jące zaburzenia Ja w schizofrenii $(2003,2004)$}

Nieznański [55] badał zależności między własnościami formalnymi struktury Ja a sprawnością monitorowania realności u osób z rozpoznaniem schizofrenii. Monitorowanie realności w psychologii poznawczej polega na odróżnianiu źródła wewnętrznego od źródła zewnętrznego informacji. Autor w swoich badaniach weryfikował hipotezę zakładającą, iż trudności w określeniu własnej tożsamości przez pacjentów ze schizofrenią mogą wiązać się z niezdolnością do trafnej oceny, czy rozpoznawany bodziec był wcześniej wytworzony przez Ja czy nie-Ja. W badaniu oceniano strukturę Ja u 41 osób z rozpoznaniem schizofrenii $\mathrm{w}$ stabilnym stanie psychicznym, wyodrębniając następujące główne miary opisujące własności formalne struktury Ja: poczucie stabilności Ja w czasie, stopień odrębności struktury Ja, stabilność i odrębność schematu Ja oraz zróżnicowanie obrazu samego siebie.

Do tego celu wykorzystywano listę 50 cech człowieka opracowaną przez Lewicką [56], a sposób oceny własności struktury Ja zapożyczono z narzędzi badawczych bazujących na poznawczej koncepcji tożsamości i opracowanych przez Jarymowicz [57].

Wykazano, że podstawowe własności struktury Ja były w istotny sposób związane z rodzajami błędów monitorowania realności. Pacjenci, u których obraz samych siebie był słabo określony lub w znacznym stopniu zbieżny z obrazem innych ludzi (którzy wybierali zaledwie kilka cech lub zaznaczali prawie wszystkie przymiotniki z listy), byli skłonni do przyswajania jako własnych informacji, które w rzeczywistości nie pochodziły od nich. Pacjenci, u których zaobserwowano duże rozbieżności między obrazem samych siebie i „siebie dawnych”, czyli z brakiem stabilności $J a$, istotnie częściej błędnie przypisywali własne słowa źródłu zewnętrznemu. Wyniki uzyskane przez autora wskazują na istnienie korelacji pomiędzy poziomem wypracowania struktury Ja a ich zdolnością identyfikowania własnej aktywności poznawczej oraz że jednym z mechanizmów zacierania różnic między Ja a „otoczeniem” są błędy monitorowania realności.

W innym swoim badaniu dotyczącym podstawowych cech schematu Ja w schizofrenii, autor wskazuje, iż pacjenci w porównaniu do osób zdrowych mają większe 
poczucie zmian własnej osobowości z biegiem czasu i mniejszy poziom odrębności schematu Ja-inni [58].

\subsection{Wyniki badań Mirosławy Huflejt-Łukasik doty- czące zaburzenia Ja w schizofrenii (2010)}

Huflejt-Łukasik [1] w pracy „Ja i procesy samoregulacji” przedstawiła wyniki swoich badań dotyczących tożsamości, samooceny, procesów samoregulacji oraz w ich kontekście - różnic między osobami zdrowymi a pacjentami z zaburzeniami psychicznymi, w tym schizofrenii. Wyniki badań wskazują, iż podstawowe zmienne autorskiej koncepcji - klarowność obrazu Ja, cechy struktury Ja idealnego, autokoncentracja i samoocena - wydają się odzwierciedlać ważne aspekty Ja i procesów samoregulacji, które wyznaczają różnice pomiędzy zdrowiem psychicznym a zaburzeniami psychicznymi. Im mniej klarowny obraz własnego Ja oraz mniej hierarchiczna i sztywniejsza struktura Ja idealnego, tym większa autokoncentracja, zwłaszcza koncentracja na Ja prywatnym. Mniej klarowny obraz Ja oraz większa autokoncentracja wiążą się z niższą samooceną.

Autorka wykazała, że osoby z zaburzeniami psychicznymi, w tym ze schizofrenią, postrzegają siebie, własne $J a$, jako mniej jasne i pewnie zdefiniowane, mniej stabilne wewnętrznie i mniej stabilne w czasie. W pracy tej analizowała również strukturę Ja idealnego, która okazała się mniej elastyczna u osób z zaburzeniami psychicznymi, w tym u osób ze schizofrenią, co było związane z wysokim poziomem lęku. Cechy sztywnej struktury Ja idealnego, takie jak większa siła wzajemnych powiązań między standardami $J a$, mniejsze zróżnicowanie i zhierarchizowanie ich struktury, służą u osób ze schizofrenią ochronie przed niepożądanymi zmianami w obrębie $J a$ idealnego. Z drugiej zaś strony takie zjawiska zwiększają autokoncentrację, skutkując zakłóconą samoregulacją.

\section{Podsumowanie}

Przedstawienie różnych wyników badań i koncepcji Ja w odniesieniu do schizofrenii może stanowić ważne uzupełnienie rozważań dotyczących istoty tego zaburzenia. W tworzonej obecnie nowej klasyfikacji ICD-11 planowane jest uwzględnienie zaburzenia self jako jednego $\mathrm{z}$ kryterium diagnostycznego schizofrenii [59]. W ostatnich czasach obserwuje się renesans podejścia fenomenologicznego w badaniach nad schizofrenią. Może to być dowodem na niewystarczającą moc współczesnych klasyfikacji psychiatrycznych opartych na podejściu Schneiderowskim w trafnym identyfikowaniu pacjentów cierpiących na schizofrenię z jednej strony i równocześnie na zubożenie rozumienia przeżyć pacjenta i trudnościach $\mathrm{w}$ znalezieniu najlepszej formy jego terapii - z drugiej. Zaprezentowane $\mathrm{w}$ artykule wyniki badań i poglądy polskich autorów dotyczące tego zagadnienia stanowią cie- kawy, choć niezbyt dobrze znany na świecie wkład do badań w zakresie zaburzeń Ja w schizofrenii. Należy mieć nadzieję na dalszy rozwój badań dotyczących problematyki zaburzeń Ja w schizofrenii w kontekście m. in. poszukiwań biologicznego podłoża obserwowanych zaburzeń, możliwości wczesnej interwencji, poprawy wglądu chorobowego, czy rozwoju form psychoterapii, mającej na celu przywrócenie Ja centralnego miejsca w komunikacji ze sobą i światem.

\section{Conflict of interest}

The authors have declared no conflict of interest.

\section{References:}

1. Huflejt-Łukasik M. Ja i procesy samoregulacji: różnice między zdrowiem a zaburzeniami psychicznymi. Warszawa; Wydawnictwo Naukowe Scholar: 2010.

2. Łukaszewski W. Osobowość. Struktura i funkcje regulacyjne. Warszawa; PWN: 1974.

3. Reykowski J. Osobowość jako centralny system regulacji i integracji czynności. W: Tomaszewski T. red., Psychologia. Warszawa; PWN: 1975, s. 762-825.

4. Jakubik A. Obraz własnej osoby a pobyt w hitlerowskich obozach koncentracyjnych. Problemy teoretyczno-metodologiczne. Przegl Lek. 1981; 38(1): 15-26.

5. Jarymowicz M, Szustrowa T. Poczucie własnej tożsamości. W: Reykowski J. red., Osobowość a społeczne zachowanie człowieka. Warszawa; KiW: 1980, s. 439-473.

6. Kępiński A. Schizofrenia. wyd. 2, Warszawa; PZWL: 1974.

7. Kępiński A. Psychopatie. Warszawa; PZWL: 1976.

8. Jakubik A. Histeria. Metodologia, teoria, psychopatologia. Warszawa; PZWL: 1979.

9. Kępiński A. Melancholia. Warszawa; PZWL: 1974.

10. Sass LA, Parnas J. Schizophrenia, consciousness, and the self. Schizophr Bull. 2003; 29(3): 427-444.

11. Parnas J, Henriksen MG. Disordered self in the schizophrenia spectrum: a clinical and research perspective. Harv Rev Psychiatry. 2014; 22(5): 251-265.

12. Nelson B, Raballo A. Basic self-disturbance in the schizophrenia spectrum: taking stock and moving forward. Psychopathology. 2015; 48(5): 301-309.

13. Zadęcki J. Zaburzenia życia uczuciowego we wczesnej schizofrenii, czyli o dążeniach, intencjach, wartościach obrazie siebie i relacjach z innymi. Niepublikowana praca doktorska 1972.

14. Zadęcki J. Ja we wczesnej schizofrenii. Kraków; Wyd. UJ: 2013.

15. Gaddis JL. Zimna wojna. Historia podzielonego świata. Kraków; Znak: 2007.

16. Kozielecki J. Psychologiczna teoria samowiedzy. Warszawa; PWN: 1986.

17. Zaborowski Z. Świadomość i samoświadomość człowieka. Warszawa; Eneteia: 1998.

18. Steuden S. Dynamika zmian osobowości u osób z rozpoznaną schizofrenią. Lublin; Wyd. KUL: 1997.

19. James W. The principles of psychology. Vol 1. London; McMillan: 1890.

20. Ciupak A. Z badań nad zmianą obrazu siebie u chorych na psychozy schizofreniczne. Pamiętnik III Lubelskich Spotkań Naukowych. Lublin; AM: 1993, 163-171.

21. Rogers C. Teoria terapii, osobowości i relacji interpersonalnych. Warszawa; Wydawnictwo Zielone Drzewo. Instytut Psychologii Zdrowia PTP: 2016 
22. Prochaska JO, Norcoss JC. Systemy psychoterapeutyczne. Analiza transteoretyczna. Warszawa; Wyd. Instytutu Psychologii Zdrowia: 2006

23. Leary MR, Cottrell CA, Phillips M. Deconfounding the effects of dominance and social acceptance on self-esteem. J Pers Soc Psychol. 2001; 81(5): 898-909.

24. Zaborowski Z. Psychospołeczne problemy samoświadomości. Warszawa; PWN: 1989.

25. Gałdowa A. Klasyczne i współczesne koncepcje osobowości. Kraków; Wyd. Uj; 1999.

26. Krzyżewski K, Kozberuk A. Specyfika psychologicznego ujmowania tożsamości. W: Gałdowa A. red. Tożsamość człowieka. Kraków; Wyd. UJ: 2000, s. 17-35.

27. Płużek Z. Człowiek w poszukiwaniu siebie. W: Darowski R. red. Człowiek, istnienie i działanie. Kraków; WAM: 1974, s. 9-26.

28. Chlewiński Z, Grzywa A. Urojeniowa wizja świata. Warszawa; Wiedza Powszechna: 1992.

29. Jarymowicz M. Psychologiczne podstawy podmiotowości. Warszawa; PWN: 2008

30. Sokolik M. Psychoanaliza i Ja - kliniczna problematyka poczucia tożsamości. Warszawa; Agencja Wydawnicza Santorski \& Co: 1993.

31. Gabbard GO. Psychiatria psychodynamiczna w praktyce klinicznej. Kraków; Wyd. UJ: 2009.

32. Zalewska M. Dziecko $\mathrm{w}$ autoportrecie z zamalowaną twarzą. Warszawa; Santorski i S-ka: 1998.

33. Henriksen MG, Parnas J. Self-disorders and schizophrenia: a phenomenological reappraisal of poor insight and noncompliance. Schizophr Bull. 2014; 40(3): 542-547.

34. Kozielecki J. Koncepcje psychologiczne człowieka. Warszawa; Wydawnictwo Akademickie ŻAK: 2000.

35. Reykowski J. Nastawienia egocentryczne a nastawienia prospołeczne. W: Reykowski J. red. Osobowość a społeczne zachowanie się ludzi. Warszawa; KiW: 1980, s. 167-228.

36. Reykowski J, Kochańska G. Szkice z teorii osobowości. Warszawa; Wiedza Powszechna: 1980

37. Zaborowski Z. Teoria treści i form samoświadomości. Warszawa; Wydawnictwo Akademickie ŻAK: 2000.

38. Minkowski E. Z zagadnień schizofrenii. Neurol Neuroch Psychiatr Pol. 1957; 7(4): 495-503.

39. Stahghellini G, Fuchs T. One century of Karl Jaspers' Psychopathology. Oxford, UK; Oxford University Press: 2013.

40. Jakubik A. Psychiatria fenomenologiczna w ujęciu Antoniego Kępińskiego. Psychiatr Pol. 1980; 14(4): 395-401.

41. Jakubik A, Masłowski J. Antoni Kępiński - człowiek i dzieło. Warszawa; PZWL: 1981.

42. Kępiński A. Rytm życia. Warszawa; PZWL: 1972.

43. Jakubik A. Koncepcja „metabolizmu informacyjnego”. Psychiatr Pol. 1980; 14(6): 641-647.

44. Kępiński A. Lęk. Warszawa; PZWL: 1977.

45. Creswell JW. Qualitative inquiry and research design: Choosing among five approaches Thousand Oaks, CA; Sage: 2007.

46. Heidegger M. Being and Time. London, UK; SCM Press: 1962.

47. Cechnicki A. Społeczny kontekst psychiatrii. W: de Barbaro B. red. Konteksty psychiatrii. Kraków; Wyd. UJ: 2014, s. 121-146.

48. Rzewuska M. Charakterystyka przebiegu schizofrenii paranoidalnych. Analiza zależności pomiędzy obrazem treści wytwórczych i ich dynamiką w przebiegu psychoz. Rozprawa habilitacyjna. Warszawa; IPiN: 1988.

49. Hochlewicz A, Wciórka J. Zaburzenia poczucia siebie w schizofrenii w ujęciu Christiana Scharfettera. Post Psychiatr Neurol. 1997; 6(3): 295-308.
50. Wciórka J, Anczewska M, Charaziński M, Gołębiewska M, Nurowska K, Skowrońska J, et al. Ocena rzetelności i trafności próbnej wersji Klinicznej Oceny Zespołu Schizofrenicznego (KOZS). Psychiatr Pol. 1997; 31(1): 71-86.

51. Overall JE, Gorham DR. The Brief Psychiatric Rating Scale. Psychol Rep. 1962; 10(3): 799-812.

52. Andreasen NC. Scale for the Assessment of Positive Symptoms (SAPS). Iowa City; University of Iowa: 1984.

53. Andreasen NC. The Scale for the Assessment of Negative Symptoms (SANS): conceptual and theoretical foundations. Br J Psychiatry. 1989; 155(Suppl 7): 49-52.

54. Kay SR, Fiszbein A, Opler LA. The positive and negative syndrome scale (PANSS) for schizophrenia. Schizophr Bull. 1987; 13(2): 261-276.

55. Nieznański M. Własności struktury “ja” a zaburzenia monitorowania źródła informacji u osób chorych na schizofrenię Psychiatr Pol. 2004; 38(5): 819-832.

56. Lewicka M. Lista określeń do opisu właściwości człowieka. Przegl Psychol. 1983; 26: 703-713.

57. Jarymowicz M. Odrębność schematów Ja-My-Inni a społeczne identyfikacje. Przegl Psychol. 1993; 1: 7-26.

58. Nieznański M. The self and schizophrenia: a cognitive approach. Swiss J Psychol. 2003; 62: 45-51.

59. Gaebel W, Zialasek J, Falkai P. Psychotic disorders in ICD-11. Die Psychiatrie. 2015; 2: 71-76.

\section{Correspondence address}

Hanna Karakuła Juchnowicz

I Klinika Psychiatrii, Psychoterapii i Wczesnej Interwencji UM w Lublinie

ul. Głuska 1

20-439 Lublin

Phone: +48 817487307

E-mail: hannakarakulajuchnowicz@umlub.pl

Received: 1.08.2017

Revised: 7.08.2017,22.08.2017

Accepted: 23.08.2017

Published: 30.08.2017 